\title{
Luminescence centres in dried urine samples containing urate and oxalate salts
}

\author{
Bordun O.M. and Drobchak O.Z. \\ Ivan Franko National University of Lviv, 50 Dragomanov St., \\ 79005 Lviv, Ukraine E-mail: bordun@electronics.wups.lviv.ua
}

Received: 03.03.2009

\begin{abstract}
Photoexcitation and luminescence spectra of urea and dried urine samples are studied. The obtained spectra are deconvolved into elemental components by means of Alentsev-Fock's technique. The luminescence bands of the urea and the dried urine samples with the maxima located near 2.2 and $2.64 \mathrm{eV}$ are shown to be caused by $n \rightarrow \pi^{*}$-transition of non-bonding electrons in heteroatoms $\mathrm{O}$ and $\mathrm{N}$. The luminescence bands of the urea and the urine with urate salts reveals the maximum near $3.64 \mathrm{eV}$, which is caused by $n \rightarrow \sigma^{*}$-transition associated with redistribution of electron density in the carbonyl group. The luminescence band with the maximum near $1.85 \mathrm{eV}$ is linked to the luminescence of urate salts in pathological urine.
\end{abstract}

Key words: luminescence spectra, urine, urea, urates, oxalates.

PACS: $87.15 . \mathrm{M}$

UDC: 535.37

\section{Introduction}

Researches of water-salt metabolism play an important part in modern physiology of living organisms and enable to elucidate deviations from standard functioning of separate organs. Beside of its purely theoretical value, the problem of the water-salt metabolism is essential for therapy of kidney and some other diseases, which occur as a result of dysfunctioning or metabolic disturbances in a human body.

Kidneys are the main organs that maintain constant physico-chemical characteristics of internal liquids. Urine as a product of kidney activity may serve an informational basis for the diagnostics of a human body. Metabolic disturbances lead to the appearance of salts in the urine which, as a rule, should not be present there. Oxalates $\mathrm{Me}_{2}(\mathrm{COO})_{2}$, urates $\mathrm{MeC}_{5} \mathrm{H}_{3} \mathrm{O}_{3} \mathrm{~N}_{4}$ and phosphates $\mathrm{Me}_{2} \mathrm{PO}_{4}$ are among them. Examination of luminescence properties of these kinds of salts is of the utmost importance for enlarging fields of medical diagnostics and could be applied, along with other optical and biochemical methods, in the early diagnostics [1-5]. The main purposes of this work are studying the luminescence of normal and pathological urine and urea (as a main component of the urine), along with ascertaining the corresponding luminescence centres and their nature. 


\section{Experimental technique}

In our experiments we studied urine samples obtained from the clinical laboratory of specialised hospital (Lviv region). All the samples were preliminarily subjected to a biochemical analysis. Two or three urine drops drifted on a quartz plate heated to $50^{\circ} \mathrm{C}$. The studies of the dried urine samples were carried out after its evaporation. All the samples were prepared and studied under the same conditions. Finally, the high-pure raw materials of urea were used as urea samples.

A lamp DKsEl-1000 supplied with a ZMR-3 monochromator was used as an excitation source. The luminescence was measured under excitation with a nitrogen laser (an impulse regime, the excitation wavelength of $337.1 \mathrm{~nm}$ (or $3.68 \mathrm{eV}$ )) and an argon laser M-931 with the excitation wavelength of $459.9 \mathrm{~nm}(2.71 \mathrm{eV})$. The luminescence of samples was analysed with a monochromator SF-4A and recorded by means of photomultiplier FEU-51, of which signal was inputted to a potentiometer PDA-1. An invariable quantity of light quanta was kept by a system for automatic control of input gap of the monochromator.

The studies of cathodoluminescence properties were performed in the conditions of impulse regime of electron excitation. The measurements of cathodoluminescence spectra were accomplished with a device based on spectrophotometer SF-4A. The spectra obtained so were recorded in a reflecting geometry using a photomultiplier FEU-79 and its signal was inputted to a potentiometer PDA-1. The electric circuit provided a zero potential at the samples during the measurements of cathodoluminescence.

The luminescence studies were carried out using laser, cathode and lamp excitations in the spectral region of 3.0-5.5 eV $(225-400 \mathrm{~nm})$. Standard software was utilised in our studies in order to process the spectra.

\section{Results and Discussion}

The excitation spectra of the luminescence of dried urine samples (both normal and those with a presence of urate and oxalate salts) and urea $\mathrm{CO}\left(\mathrm{NH}_{2}\right)_{2}$ are shown in Fig. 1 and
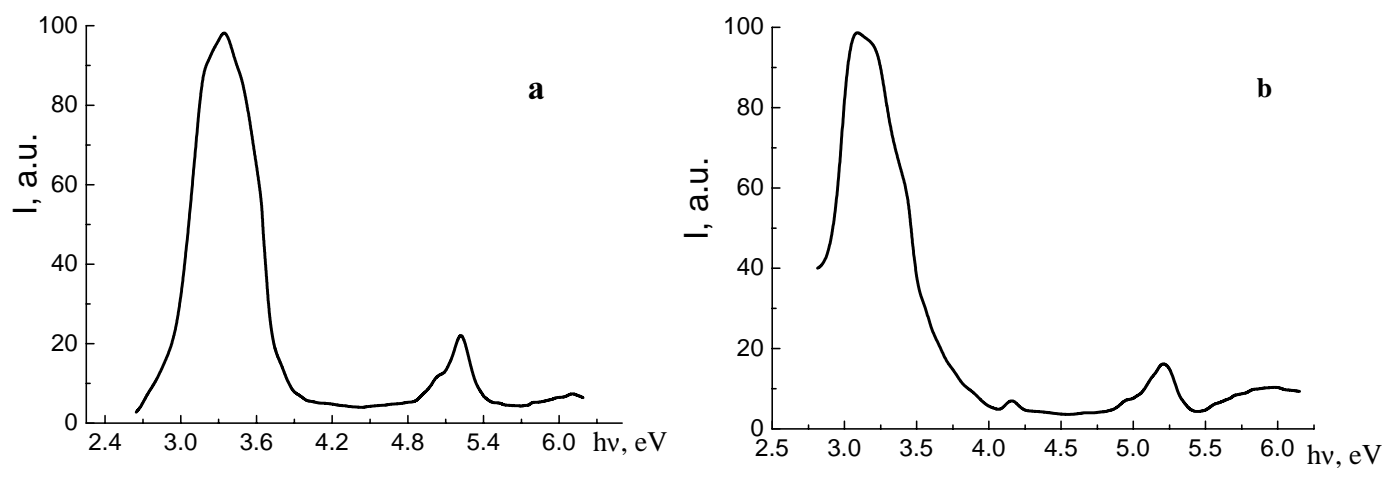

Fig. 1. Luminescence excitation spectra of the urea (a) and the dried urine samples with no composition deviations (b). The measurements are performed at $\mathrm{T}=295 \mathrm{~K}$ with a light filter of ZhS-12 type.

Ukr. J. Phys. Opt. 2009, V10, №3 


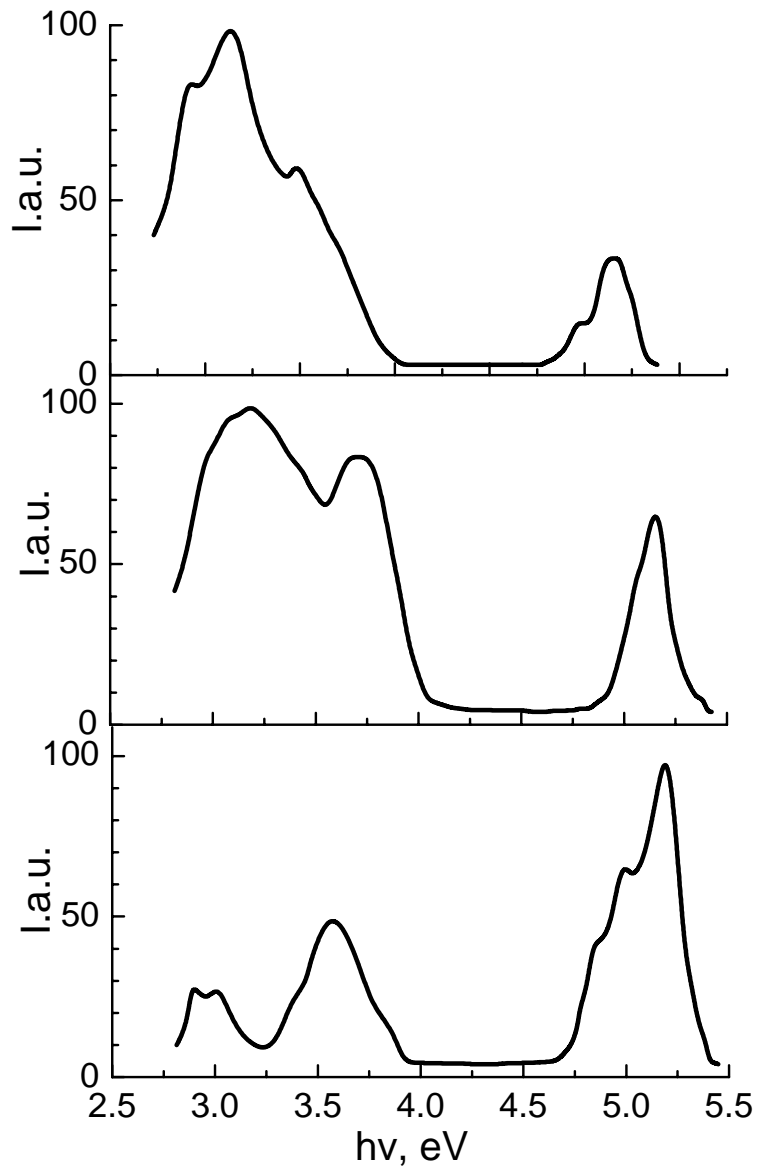

Fig. 2. Luminescence excitation spectra of the dried urine samples containing phosphate (a), oxalate (b) and urate (c) pathological salts. The measurements are performed at $\mathrm{T}=295 \mathrm{~K}$ with a light filter of ZhS-12 type.

in the pathological urine salts refer to those having unfilled electronic shells and manifesting such the effect (see [9]). The maxima in the excitation spectra positioned near $5.2 \mathrm{eV}(238 \mathrm{~nm})$ and $5.9 \mathrm{eV}(210 \mathrm{~nm})$ demonstrate this clearly. Taking into account similarity of the structure of all the obtained excitation spectra of luminescence, one can assume that it is glowing of the urea that forms the excitation spectra of the urine. This supports the results [10] testifying that the absorption of urea reveals three main urine components: urea, urea acid and tyrosine. Finally, this allows us to use a general approach when studying the nature of separate bands in the spectra of luminescence excitation.

Reminding some facts concerned with the luminescence centres under test would be not out of place. The studies of electronic spectra of some carbamides by means of electron spectroscopy and quantum chemistry aimed at elucidating their long-wave absorption have been presented in [11], along with the appropriate interpretation of its nature in connection with the urea molecule. In the work [12] the long-wave absorption 
band peaked approximately at $5.4 \mathrm{eV}(230 \mathrm{~nm})$ has been measured accurately and related to an $n-\pi *$-transition. Again, a "blue shift" of this band detected with increasing solvent polarity could be caused by the same $n-\pi^{*}$-transition. Since just this effect has been observed when some mineral acids are added to the urea solution, one can surely interpret the transition near $5.4 \mathrm{eV}$ as the $n-\pi^{*}$-transition [11]. Analysis of the absorption spectra of urea and calculations of its electronic structure according to the Hukel's method has been performed in the study [13]. Taking the results obtained in [13] into account, one gets one more ground for assuming that this band is caused by the $n-\pi^{*}$-transition. Besides, it is known that this absorption is associated with redistribution of electronic density in the carbonyl group $\mathrm{C}=\mathrm{O}$ [12]. At the same time, the nature of the higher-energy transition occurring in the region of $6.0-7.0 \mathrm{eV}(180-205 \mathrm{~nm})$ has not been reliably identified. In particular, the calculations [12] have meant a participation of Ridberg's states in formation of these absorption bands.

It is understood that any physical and, in particular, optical properties of the urea and dried urine samples should be determined by their constituents - molecular anions and cations. At the same time, they depend additionally on nonstoichiometry of the chemical composition appearing due to deviations of urine composition from a norm in the presence of impurities. Since the urea molecule has electron donor group, it can form complexes and, in crystalline states, a weak intermolecular bond $\mathrm{N}-\mathrm{H} \ldots \mathrm{O}$ [14]. The crystalline structure of the urea is described by the space group $\overline{\mathrm{P}} \overline{4} 2_{1} \mathrm{~m}$ [15] and is considered to represent rather complex formation. Here the hydrogen ions are complexing agents, while the negative oxygen and nitrogen ions are ligands. The urea molecules form a stable tetragonal structure by means of hydrogen bond in crystalline states, which have molecular cavity. This can result in a spatial formation involving impurity or urine components. It is these formations that determine the absorption processes and secondary scattering, as well as the luminescence revealed by the formation in the presence of no additional activating impurity.

The non-elementary low-energy excitation band centred at $3.2 \mathrm{eV}(385 \mathrm{~nm})$ is, most likely, to be caused by such a kind of glowing. The assumption is supported by the fact that the presence of pathological salts affects the intensity and shape of this band much stronger in comparison with the other bands [4]. The above considerations agree with the results [16], where the electron spectra of urine have been studied in the region of $2.25-6.2 \mathrm{eV}(200-550 \mathrm{~nm})$. The maximum present in the spectra of urine is located near $3.4 \mathrm{eV}(360 \mathrm{~nm})$ [16], though deviations from the norm in the urine composition lead to some changes in the spectral position of this band. For example, increased protein content in the urine imposes a shift of the absorption maxima towards the short-wave region [16].

Our luminescence data for the urea and the dried urine samples show also that the glowing of the samples results in a complex non-elementary band that depends on the type and the energy of its excitation. In this respect the complex band as a whole is not informative enough, since much information is involved in elemental parameters of individual subbands contained in that band. In other words, there is a necessity for

Ukr. J. Phys. Opt. 2009, V10, №3 

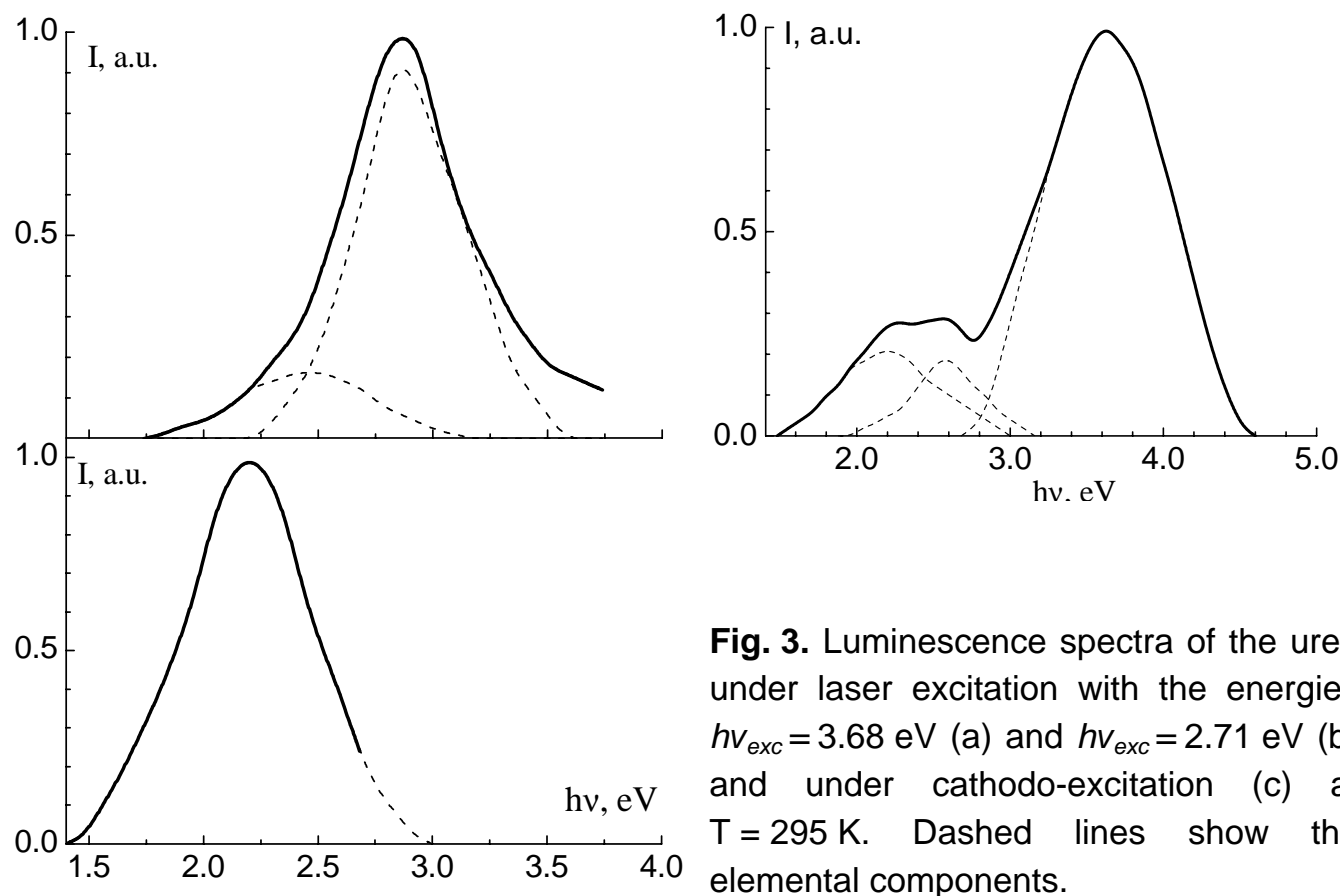

Fig. 3. Luminescence spectra of the urea under laser excitation with the energies $h v_{\text {exc }}=3.68 \mathrm{eV}$ (a) and $h v_{\text {exc }}=2.71 \mathrm{eV}$ (b) and under cathodo-excitation (c) at $\mathrm{T}=295 \mathrm{~K}$. Dashed lines show the elemental components.

deconvolving complex spectra into elemental bands, consisting in determination of their number, shapes and positions on the energy scale. The most prevalent method for deconvolving of complex spectra into elemental bands, which is used in the present study, is the so-called Alentsev-Fock's method [17]. In order to check additionally the maxima positions of the elemental bands we have also employed the technique that consists in differentiating the luminescence spectra [18].

Our studies have displayed that the luminescence spectra of the urea and the dried urine samples may contain different numbers of elemental bands, depending on the excitation energy and type (see Fig. 3 to Fig. 6). In particular, the spectra of the samples under test (both normal and those including the oxalate salts) are composed of the two elemental bands with the maxima located near 2.20 and $2.65 \mathrm{eV}$ (563 and $468 \mathrm{~nm}$, respectively) under excitation with the nitrogen laser of LGI-21 type (see Fig. 3a, Fig. 4a and Fig. 6a), while the spectra of samples including the urate salts consist of the two elemental bands with the maxima near 1.85 and $2.15 \mathrm{eV}$ (670 and $577 \mathrm{~nm}$, respectively see Fig. 5a). At the same time, in the case of excitation with the argon laser of M-931 type the intrinsic luminescence spectra manifest a single low-energy luminescence band with the maximum near $2.20 \mathrm{eV}(562 \mathrm{~nm}$ ) (see Fig. 3b, Fig. 4b and Fig. 5b) or near $2.15 \mathrm{eV}(575 \mathrm{~nm})$ for the urine samples containing the urine salts (Fig. 5b). The luminescence spectra of the urea and the dried urine samples containing the urate salts include one more additional band located near $3.64 \mathrm{eV}(340 \mathrm{~nm})$ if we deal with cathodoexcitation at the electron energy of $10 \mathrm{keV}$. The typical luminescence bands separated for the urea and the dried urine samples are described in Table 1. A comparison of all the 

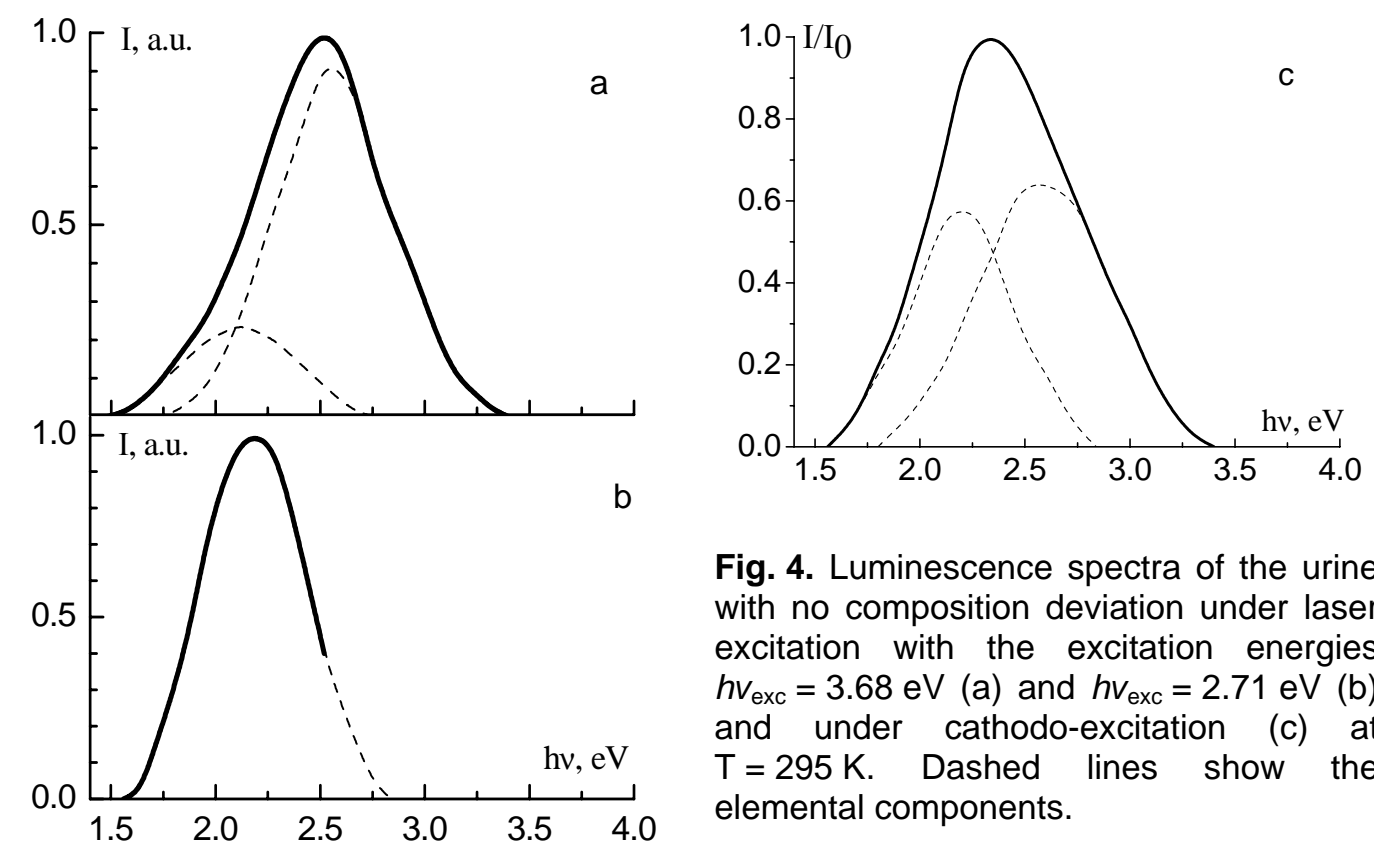

Fig. 4. Luminescence spectra of the urine with no composition deviation under laser excitation with the excitation energies $h v_{\text {exc }}=3.68 \mathrm{eV}$ (a) and $h v_{\text {exc }}=2.71 \mathrm{eV}$ (b) and under cathodo-excitation (c) at $\mathrm{T}=295 \mathrm{~K}$. Dashed lines show the elemental components.
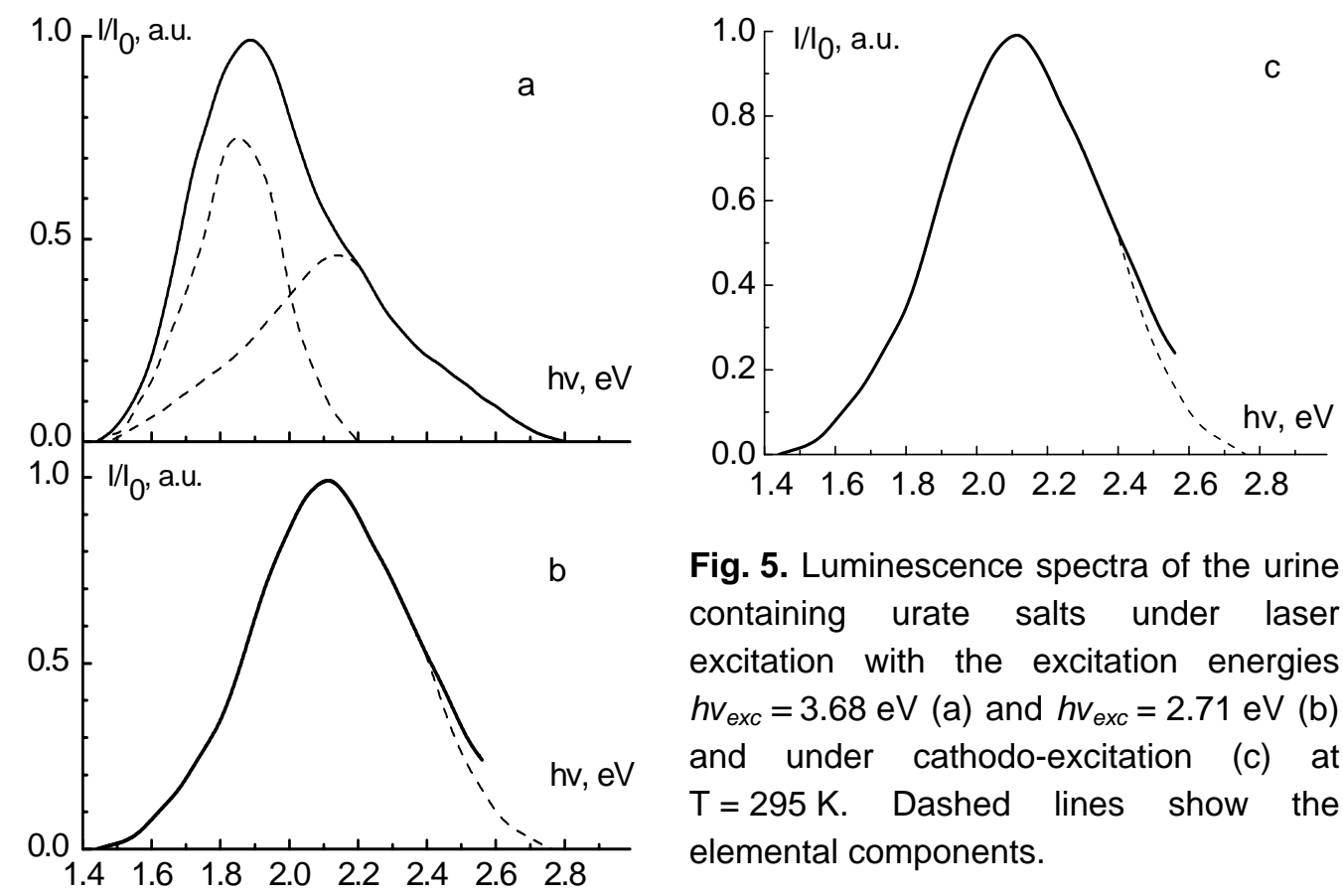

Fig. 5. Luminescence spectra of the urine containing urate salts under laser excitation with the excitation energies $h v_{e x c}=3.68 \mathrm{eV}(\mathrm{a})$ and $h v_{e x c}=2.71 \mathrm{eV}(\mathrm{b})$ and under cathodo-excitation (c) at $T=295 \mathrm{~K}$. Dashed lines show the elemental components.

results obtained by us demonstrates that the luminescence of different samples has a common nature and is caused by electron processes linked to molecular orbitals of the urea.

The calculations performed in the work [19] for the electron density and band structure of the urea have shown that the higher occupied molecular orbital has a complex structure influenced by $\mathrm{C}=\mathrm{O}$ and $\mathrm{C}-\mathrm{N}$ bonds. Robi-Devidson number for the $\mathrm{C}-\mathrm{N}$ and $\mathrm{C}=\mathrm{O}$ bonds amounts to 1.49 and 2.45 , respectively [20]. It has also been shown that the 

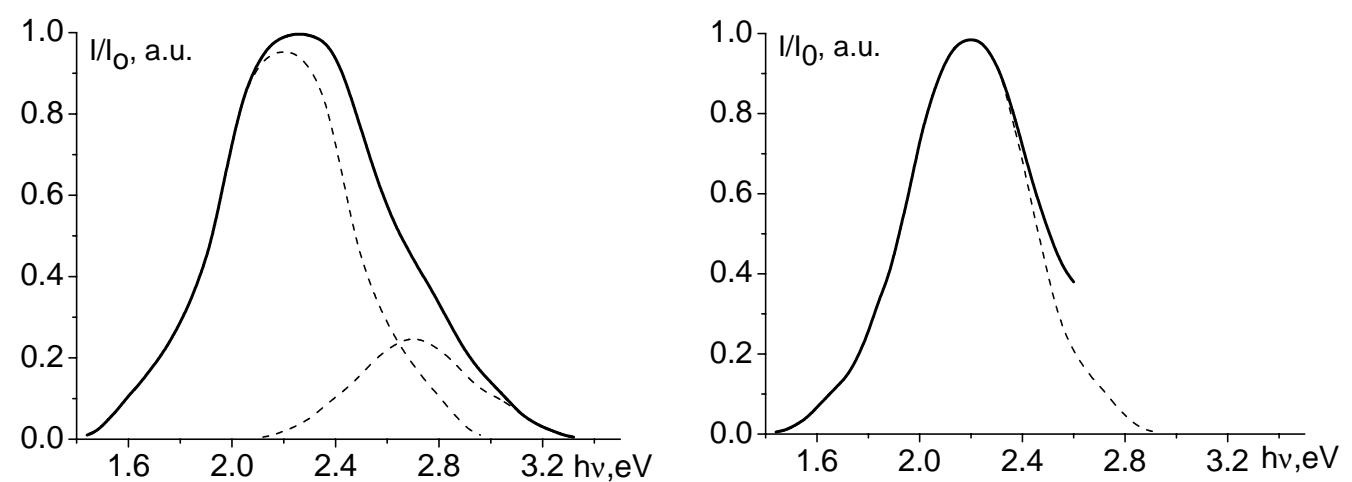

Fig. 6. Luminescence spectra of the urine containing oxalate salts under laser excitation with the excitation energies $h v_{e x c}=3.68 \mathrm{eV}$ (a) and $h v_{e x c}=2.71 \mathrm{eV}$ (b). Dashed lines show the elemental components.

Table 1. Spectral luminescence bands of urea and dried urine samples (normal ones and those containing pathological salts)

\begin{tabular}{|l|c|r|r|c|}
\hline \multicolumn{1}{|c|}{ Sample } & \multicolumn{4}{|c|}{ Spectral position of band maximum, eV } \\
\hline Urea & - & 2.20 & 2.65 & 3.64 \\
\hline Normal urine & - & 2.20 & 2.65 & - \\
\hline Urine containing urates salts & 1.85 & 2.15 & 2.70 & 3.64 \\
\hline Urine containing oxalates salts & - & 2.20 & 2.65 & - \\
\hline
\end{tabular}

$\mathrm{C}-\mathrm{N}$ bond is weaker than the $\mathrm{C}=\mathrm{O}$ bond, whereas the $\mathrm{C}=\mathrm{O}$ bond contributes much stronger to formation of occupied molecular orbitals of the urea. In accordance with [19], higher occupied orbitals of the urea are formed by the energy levels of $\mathrm{O}$ and $\mathrm{N}$. Low vacant orbitals of the urea are substantially formed by the energy levels of carbon. Taking these facts into consideration, one can assume that the luminescence spectra of urea and the dried urine samples are caused by transitions of non-bonding electrons of heteroatoms $\mathrm{O}$ and $\mathrm{N}$. In this relation one should remind the theoretical and experimental data [21] that explain a strong effect of $n$-electrons of heteroatoms $\mathrm{O}$ and $\mathrm{N}$ on the optical properties of molecules, depending on their nature and the conjugation with $\pi$-system.

The probability of $n-\pi^{*}$-transitions differs for different heteroatoms and is higher for the atoms with larger atomic radius. The energy of those transitions decreases progressively according to the series represented symbolically as $\mathrm{N}<\mathrm{O}<\mathrm{S}$ [21]. The above considerations enable one to associate the two low-energy luminescence bands of the urea and dried urine samples having their maxima at 2.20 and $2.65 \mathrm{eV}$ with the $n-\pi^{*}$ transitions of non-bonding electrons of heteroatoms $\mathrm{O}$ and $\mathrm{N}$, respectively.

On the basis of the results [12] and the calculations of state density and energy levels of the urea [19], the luminescence band with the maximum near $3.64 \mathrm{eV}$ is, most likely, induced by the $n-\sigma^{*}$-transition connected with redistribution of electron density in the carbonyl group. It is to be mentioned that intense $n-\sigma^{*}$-transitions are typical of both the amides and the urea. This assumption is also supported by the structural studies of urea- 
cation bonding with crystalline adducts of the urea [22]. It has been established that the cations bond to the oxygen in all of 26 crystalline adducts of the urea studied in the work [22]. Paying attention to the set of cations available in the urine, besides the urea, one can state that the bonds of these cations with the urea may give rise to redistribution of the electron density of $\sigma$-orbital and, as a result, this would lead to (i) lower intensity of the $n-\sigma^{*}$-transition, the case of presence of urate salts in the urine, and (ii) non-radiating deactivation of the $n-\sigma^{*}$-transition, the case of the normal urine or the presence of urate salts in the urine.

It is worthwhile that the additional low-energy band appears in the 'red' region (the maximum at $1.85 \mathrm{eV}$, i.e. $670 \mathrm{~nm}$ ) of the luminescence spectra for the dried urine samples including the urate salts. As this band does not exist in the luminescence spectra of urine and the other dried urine samples, it would be reasonable to relate the band with the urea acid salts (urates). This should be the case for the urine samples in which the urate salts are present.

\section{Conclusion}

The results obtained in the present study testify that the luminescence spectra of dried urine sample are determined by the luminescence of urea, the main component of the urine. The luminescence spectra under test have been deconvolved into elemental bands according to the Alentsev-Fock's method. All the spectra consist of the same number of individual bands. The luminescence bands with the maxima located near 2.20 and $2.65 \mathrm{eV}$ are assigned to the $n-\pi^{*}$-transitions of non-bonding electrons belonging to heteroatoms $\mathrm{O}$ and $\mathrm{N}$, respectively. The band with the maximum near $3.64 \mathrm{eV}$ present in the luminescence spectra of the urea and the dried urine samples containing urate salts is linked to the $n-\sigma^{*}$-transition owing to redistribution of electron density in the carbonyl group. Finally, the luminescence band having its maximum close to $1.85 \mathrm{eV}$ might be ascribed to glowing of the urate salts available in the pathological urine.

\section{References}

1. Gijsbers G H M, Breederverd D, Gemert M J C van and Boon T A, 1986. Optical properties of urine, blood plasma and pulmonary condensate of patients with pulmonary form of tuberculosis. Lasers Life Sci. 1: 29-48.

2. Marijnissen J P A, Jansen H and Star W M, 1989. Reagent-free clinical analysis and diagnostics. J. Urol. 142: 1351-1355.

3. Stavaren H J van, Beek J F, Keizer M and Star W M, 1995. Integrating sphere effect in whole-bladder-wall photodynamic therapy. II. The influence of urine at 458,488 , 514 and $630 \mathrm{~nm}$ optical irradiation. Phys. Med. Biol. 40: 1307-1315.

4. Bilyy O I, Bordun O M and Petruh A V, Method for determination of type of the urine salts. MPC G01 No 33/493. Declarative patent 7880 of Ukraine on useful model // Published 15/07/2005. Bull. No 7b, 2005.

5. Li Y-Q, Sui W Wu Ch and Yu L-J, 2001. Derivative matrix isopotential synchronous 
fluorescence spectroscopy for the direct determination of 1-hydroxypyrene as urinary biomarker of exposure to polycyclic aromatic hydrocarbons. Analytical Sci. 17: $167-170$.

6. Chernitskiy E A and Slobozhanina E I. Spectral luminescent methods in medicine. Minsk: Nauka i Tekhnika (1989).

7. Tyshchenko Yu A, Orlovskaya L V and Danilova V I, 1980. Electron absorption spectra of carbamide and its nitrogen derivatives. Izv. Vuzov, Ser. Fiz. 3: 23-25.

8. Posudin $\mathrm{Yu}$ N. Laser fluorimetry of biological objects. Kiev: Vysshaya Shkola (1985).

9. Golovina A P and Levshyn L V. Chemical luminescent analysis of inorganic compounds. Moscow: Khimiya (1978).

10. Guminetsky S G, Gauka O R, Kokoschuk G I, Grigorishin P M and Kirsh N L,1999. Absorption spectra of the main organic components of human urine in the absence of proteins. Proc. SPIE. 3904: 579-589.

11. Fofonova R M, Orlovskaya L V and Kuznetsova R T, 1978. Electron absorption spectra of carbamide and its nitrogen derivatives. Izv. Vuzov, Ser. Fiz. 1: 145-147.

12. Pulgarin J A M, Molina A A and Lopez P F, 1997. Direct determination of amiloride in urine using isopotential flourimetry. Analyst. 122: 247-252.

13. Figuera J M and Mendez V, 1971. Extended Hukel calculations of some ureas and thioureas. An. Quim. Real. Soc. Esp. Fis. y Quim. 67/12: 1169-1177.

14. Mullen D and Hellner E, 1978. A simple refinement of density distributions of bonding electrons. V. Bond electron density distribution in urea, $\mathrm{CO}\left(\mathrm{NH}_{2}\right)_{2}$, at $123 \mathrm{~K}$. Acta Crystallogr. B. 34/5: 1624-1627.

15. Swaminathan S, Craven B M and McMullen R K, 1984. The crystal structure and molecular thermal motion of urea at 12,60 and $123 \mathrm{~K}$ from neutron diffraction. Acta Crystallogr. B. 40: 300-304.

16. Eliseev A A, Morozova Yu P and Kozynska V A, 2000. Application of computer and informational technologies in medicine. Izv. Tomskogo Gosudarst. Univer. 269: 113-117.

17. Fock M V, 1972. Deconvolution of complex spectra into elemental bands according to generalized Alentsev's method. PIAS Transactions. 59: 3-24.

18. Owen T. Fundamentals of UV-visible spectroscopy. Waldronn: Hewlett-Packard $\mathrm{GmbH}$ (1996).

19. Pisani C. Quantum-mechanical ab-initio calculation of the properties of crystalline materials. Lecture Notes in Chemistry, 67, Heidenberg: Springer Verlag (1996).

20. Sun H and Kung P W-C, 2004. An ab initio and force field study of the gas and solid phases. J. Comp. Chem. 26/2: 169-174.

21. Karyakin A V. n-electrons of heteroatoms in hydrogen bond and luminescence. Moscow: Nauka (1985).

22. Lebioda L, 1980. Crystal structure of human prostatic acid phosphatase. Acta Crystallogr. B. 36/2: 271-275. 
23. Petrun N M and Borchenko L I. Contents of chemical compounds in human tissues and liquids. Moscow: Nauka (1964).

Bordun O.M. and Drobchak O.Z. 2009. Luminescence centres in dried urine samples containing urate and oxalate salts quadrefringence in a uniaxial crystal. Ukr.J.Phys.Opt. 10: 124-133.

Анотація. Досліджено спектри фотозбудження та люмінесценції сечовини та сухих залишків урини. Методом Алснщева-Фока спектри поділено на елементарні складові. Смуги люмінесцениії сечовини та сухих залишків урини з максимумами біля 2.2 та 2.64 еВ спричинені $n \rightarrow \pi^{*}$-переходом неподілених пар електронів гетероатомів $O$ та $N$ відповідно. Смуги люмінесиениії сечовини та урини за наявності уратних солей з максимумом біля 3.64 еB пояснено $n \rightarrow \sigma^{*}$-переходом, пов'язаним з перерозподілом електронної густини в карбонільній групі. Смугу люмінесченщії з максимумом біля 1.85 еВ пов'язано з уратними солями, наявними в патологічній урині. 